\title{
"When There Is No Vision, the People Perish." The McCord Family Papers, 1766-1945
}

\author{
by Pamela J. Miller
}

This paper identifies and describes the people uho created the McCord family papers. It proutides a brief biography of the more prominent members along with a description of their records. It focuses upon the Musemm's founder. David Ross McCord and places his papens uithin the context of bis collections.

Cette article identifie et décrit les personnes qui ont crée le fonds de la famille McCond. Il contient une courte biographie des membres les plus illustres et une description de leurs documents. Il fait une large place à David Ross McCord, fondateur du musée, et situe ses documents dans le cadre des collections de cet établissement.

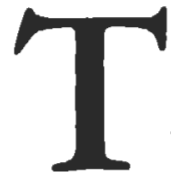

The McCord Museum will soon be expanding its facilities thanks to a generous grant from the McConnell Family Foundation. This expansion could not have taken place a minute too soon. Since the Museum reopened its doors in the refurbished McGill University Student's Union in 1971, collections have rapidly outgrown storage space. Moreover, the public has made it clear that it would like to see more than the $1 \%$ of the collections which can be exhibited presently at any given time.

The McCord Museum is largely the result of one man's vision, knowledge and energy. That man is David Ross McCord (1844-1930, Figure 1), a member of a prominent Montreal family of merchants and barristers. David Ross McCord's passion for collecting objects devoted to recounting the history of Canada probably stems from his background and upbringing. This paper will try to examine that background briefly in the context of the fourteen metres of archives created and preserved by several members of the McCord family, and now housed in the Museum which bears his name. The criteria for a discussion of a member of this large family in so brief a study are the richness of the holding created by the family member and the influence of a member on the rest of the family. The members included are: John McCord, 1711-1793, merchant; Thomas McCord, 1750-1824, John's second surviving son, a merchant, politician and police magistrate; Arthur Davidson, 1743-1807, judge and father-in-law of David Ross, 1770-1837, lawyer. Included as well are Anne Ross, 1807-1870, daugher of David Ross, who married John Samuel McCord, 1801-1865, judge, elder son of Thomas, and their son, David Ross McCord, 1844-1930, lawyer and founder of the McCord Museum.

The McCord archives tell the story of the family and they tell a little of the story of a country. To make the contents of the family archives more accessible to scholars, a twovolume inventory to the papers was published in 1986, funded by the Social Sciences and Humanities Research Council.

The McCord Museum has only 14 documents pertaining to John McCord 1711-1793, the first McCord to establish himself in Quebec City. Although uncertain of the exact date of his arrival, we know that John McCord paid $\left\{135\right.$ duty for 5,300 gallons of rum ${ }^{2}$ 
imported into Quebec in 1761 and 1762 . We also know that in 1756 he leased 207 acres of land in Longfield, County Monaghan, Ireland, for an annual rental of $\mathrm{f90}$. "Sometime between those years he arrived in Quebec with his two sons and two daughters. When his first wife died, he remarried and began a new family of whom only one child lived to adulthood. John McCord's chief business in Quebec was to "sell strong Liguors by Retail... in the house he now dwelleth..." and to "suffer no Disorders, or unlawful Games to be used in his said House, or in any Outhouse, Yard or Garden therunto belonging." For economic and perhaps social reasons, McCord like many other merchants, invested in land. In 1767 McCord and fellow-merchant Felix O'Hara, were granted 1300 acres on the South West arm of Gaspé Bay. Along with other Quebec merchants, McCord campaigned actively for an Assembly in 1773 and he was chosen president of the Quebec committee charged with drawing up a petition calling for an assembly. Sir Guy Carleton, Governor-in-Chief of British North America, reporting to the Earl of Shelburne, Secretary of State for the Southern Colonies, described John McCord as a man who:

wants neither Sense nor Honesty, and formerly kept a small Ale House in the poor Suburbs of a little Country Town in the North of Ireland, appearing zealous for the Presbiterian Faith, and having made a little Money, has gained some Credit among People of his Sort; this Person purchased some Spots of Ground, and procured Grants of more, close to the Barracks, where he run up Sheds, and placed poor People to sell his Spirits to the Soldiers, finding that his lucrative Trade has lately been checked, by inclosing the Barracks to prevent the Soldiers getting drunk all Hours of the Day and Night, He has commenced Patriot, and with the Assistance of the late Attorney General, and three or four more, egged on by Letters from Home, are at work again for an Assembly, and purpose having it signed by all they can influence: $O n$ the other Hand the better Sort of Canadians fear nothing more than popular Assemblies, which, they conceive, tend only to render the People refractory and insolent."

During the American rebellion McCord's buildings were burned by the garrison of Quebec in order to prevent them from falling into the hands of the invading American rebels and serving as a base of operations against the British garrison. In 1777 John and his son claimed $\mathfrak{x} 409 / 1 / 10$ in compensation for their loss. They then moved to Montreal where John McCord lived in a home which the family called the Grange not far from the present day Victoria Bridge. (The house later served as offices for the builders of the bridge.) Here McCord died in 1793.

Carleton's unflattering description of John McCord was not shared by later members of his family who came to look upon John as one of the fathers of the Parliamentary system in Canada. During the next century this family grew in size and influence and counted among its members men and women who participated in the social, cultural, economic, military, scientific, philanthropic and judicial life of their adopted land as it moved from colony to nation. By 1922, David Ross McCord, greatgrandson of John McCord, had opened the McCord National Museum. In 1919 he wrote to Lady Laurier soon after Sir Wilfrid's death, describing the purpose and character of his new museum which he had presented through McGill to the nation:

Vous connaissez mon ceuvre - de Bénédictin-pour Canada auquel jai eu l'honneur de dédier ma vie, et que le bon Dieu a bénie grandement au dessus de mes humble mérites. J'ai fait et je continue à faire un musée national dans le vrai et plus étendu sens du mot. McGill se lança dans la brêche pour rencontrer cet object très désirable et jusqu'à présent négligé au Canada. McGill fournit la belle bâtisse que vous connaissez au coin de la rue Sherbrooke et McTavish, et va l'entretenir. Le musée que je ferai n'est 


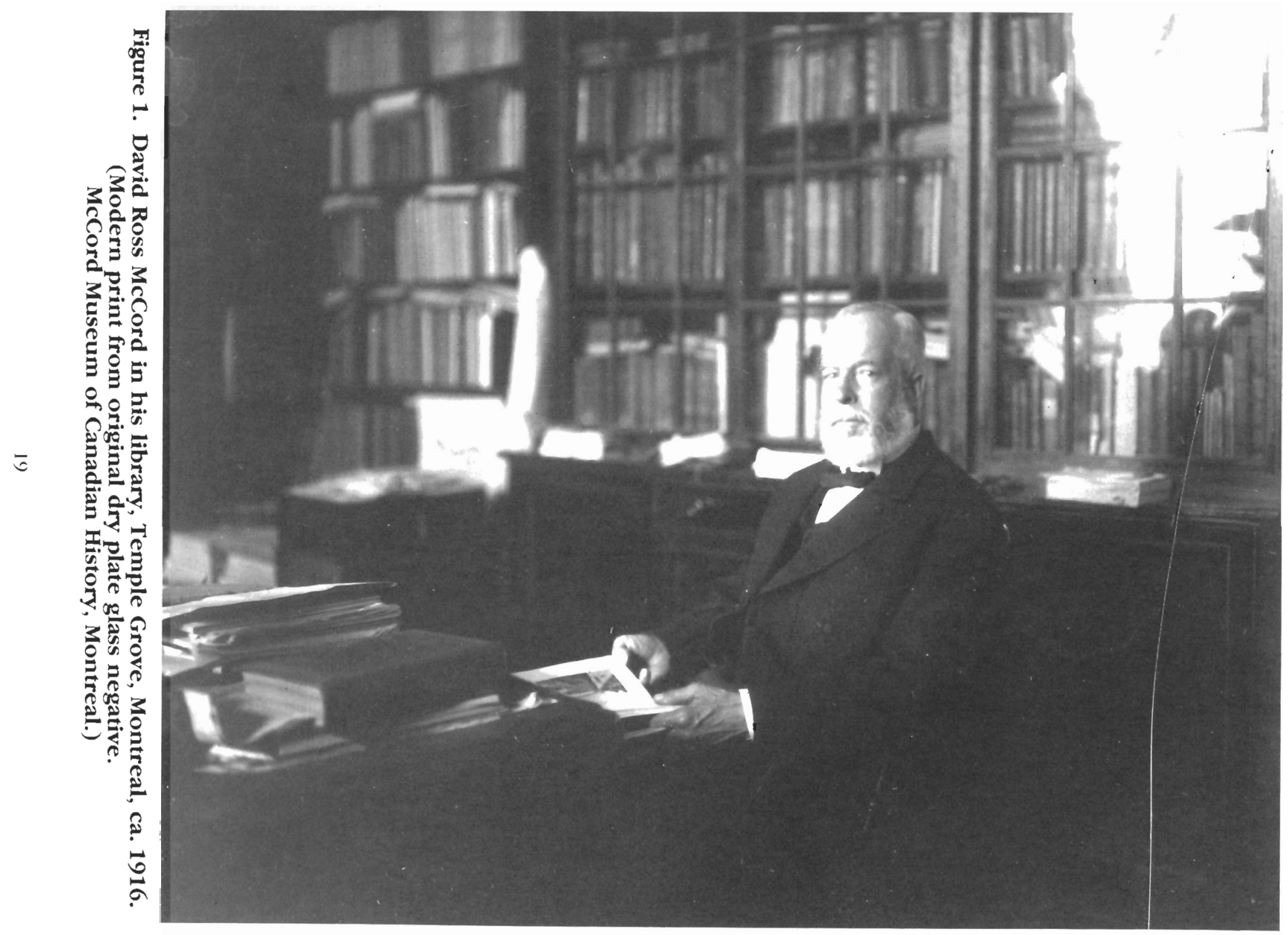


pas un Musée McGill, ni un musée protestant, et certainement pas un musée anglais. Chaque objet dans le musée sera désigné et exprimé dans les deux langues. Notre premier roi était François I., le roi de Cartier, et partant de lui, je déroulerai le beau panorama de notre histoire jusqu'aujourd'hui. En lisanr cette lettre vous voyez que je tombe absolument dans la ligne, et j'enseigne les principes auxquels votre associé marital dans ce monde a dédié sa vie, - l'union des deux races. Et non seulement Sir Wilfrid, mais vous, Madame, aussi bien que lui dédiez vos talents à ce but qui mérite tous nos efforts. L'objet de cette lettre est de vous prier d'honorer ce Musée National en lui présentant les souvenirs, les objets les plus précieux que vous possédez de Sir Wilfrid à fin de conserver sa mémoire ici au centre du Canada..."

To return to the family, Thomas McCord, 1750-1824, the second generation of Canadian McCords, was only a lad when he arrived in Quebec with his father John McCord. He too became a merchant, and established himself in Montreal, forming partnerships at various times with many well-known merchants among them George King, James McGill, John Richardson and Thomas Forsyth. One of his most important enterprises was the fief Nazareth, a sub-fief which he leased from the Hôtel-Dieu for $£ 25$ a year. In subsequent years he acquired further leases, and attempted to develop his farm, importing roots and seeds from England. In 1795 he wrote to his London agent and friend Jacques Terroux:

There is also to be had at the same Shop, a Small Pamphlet, entitled"twenty interesting communications on Gardening and Husbandry, by Jededeah Simmons, price $5 /$ it is sealed up, and like Matrimony or Masonry, not to be known but by trial-however the Sum is not large, and is unlike them in one respect; the worst is known at once-if it contains one new and Valuable
Communication, it is well worth the Money-The Writer is Improving a farm, and Endeavouring in this frozen Climate to make a good Garden, - therefore would be much Oblidged to $\mathrm{Mr}$. Terroux, if he can procure him a few good Garden seeds, that may be depended on."

The fief Nazareth was a shrewd investment. Situated close to the site of the future Lachine canal, it proved a valuable asset which Thomas passed on to his sons. Others too were aware of its value. In $1796 \mathrm{McCord}$ left Montreal for Ireland in order to try to sell off property he had inherited. The administration of the fief was left in the hands of Patrick Langan his friend and husband of his niece. Langan and Robert Griffin, (source of the name Griffintown) attempted to defraud McCord of his land. Upon his return, McCord sued. The suit was settled by the Privy Council in McCord's favour. The McCord papers contain 29 files, from 1799 to 1815 , pertaining to the legal problems of the Nazareth fief. They also contain much more on the fief including deeds of cession, accounts and rents, rent rolls, leases, suits and corespondence. As this section continues throughout the entire holding, the papers provide a valuable source for the study of the early economic development of this area of Montreal (Figure 2).

Thomas McCord was obliged to remain in Ireland longer than he intended. The out break of rebellion in 1798 retarded the sale of his property and while he waited, McCord joined the Yeomanry. His reasons for doing so are explained in the following letter from Dublin to his agent in London, Jacques Terroux.

Upwards of ten Thousand wretched Victims have fallen since the Commencement of this Rebellion, in a cause which truly speaking, they could have no interest in; but blinded by the persuasion of their leaders and Priests, they rushed on without Consideration, to certain destruction. I was one of a part of About 
"When There Is No Vision, the People Perish."

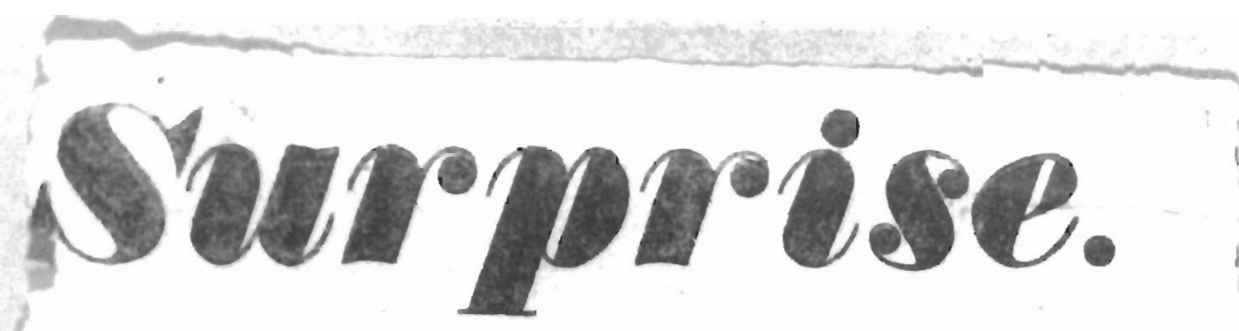

That well known English HORSE the property of Robert Straker, of Montreal, will cover Mares, this Season, at four Dollars each.

\section{SURPRIS}

will stand at the Farm of the late Thomas McCord, Esquire, Wellington-Street, St. Ann Suburb.

N. B.-Grass for Mares at THREEshillings perweek. All expenses to be paid before the Mares are taken away.

Montreal, 1 st Jung, 1825.

Figure 2. Handbill. (McCord Family Papers. McCord Museum of Canadian History, Montreal). 
800 Yeomanry, which was sent in pursuit of some thousand of the Rebels on Sunday last, - we were out three days in the Mountains, but could not come up with them-they had Escaped from the County Wexford, and had come within about 20 Miles of this City. By this you will perceive that $I$ am a Yeoman almost a Stranger in this Country, I might have avoided it, but having resolved on staying here, I considered it my duty in such times, to give the litrle help which was in my power, to the Maintenance of order and good Government:...I w would (have been) ashamed to be found out of the Ranks of the Defenders of our King \& Happy Constitution.'

Repression of the rebellion also promised better land markets, and public gratitude, which he was never reluctant to translate into more tangible personal benefits.

During McCord's absence from Montreal between the years 1796 and 1806 , he remarried. His second wife Sarah Solomon was the half sister of Jacques Terroux and daughter of the prominent Montreal merchant Levy Solomon. A portrait of Sarah, copied by Louis Dulongpré shows Sarah to have been a rather grand lady with imposing features. A portrait of Thomas, painted by the same artist in 1819 shows the subject seated against a background of weighty volumes, befitting his position as Police Magistrate, Justice of the Peace and joint Chairman of the Court of Quarter Sessions.

The McCord Papers possess forty of Thomas McCord's letters which cover a wide range of his activities. These include ten letters to Jacques Terroux during McCord's stay in Ireland, as well as letters from James McGill about petitions to the House of Assembly, from William McGillivray about shipping drugs and books aboard his ship the "Isaac Todd," and from Judge James Reid about McCord's manuscript index to Provincial ordinances and statutes.
Another sixty-four files of assorted bills and receipts from 1806 to 1824 provide a directory of merchants, businessmen and craftsmen in Montreal at that rime. These papers include transportation charges from John Molson, bills for hay, subscriptions, soap, games, musical instruments, blacksmiths and carpenters. They contain Louis Dulongpré's bills for Thomas' and Sarah's portraits which provide useful information to the art historian and important documentation for curators interested in identifying and dating works of art.

There are also bills for the education of his children at the Petit Seminaire, as well as for private tutors John Doty and Alexander Skakel, and Charlotte Berczy daughter of the well-known artist William Berczy who gave drawing lessons to his boys.

Although McCord played an active part in the public life of the city of Montreal, his papers contain very little about this aspect of his life. He sat in the Assembly as a member for Montreal West from 1809 to 1810 and for Bedford from 1816 to 1820 . In his capacity as a Police Magistrate he compiled an index to Provincial ordinances and statutes. He worked successfully for the establishment of a paid police force, helped to establish a House of Industry and helped organize a more effective fire prevention service for a very inflammable city.

Three children survived Thomas: Mary the daughter of Elizabeth Ellison, his first wife, and two sons by Sarah Solomon, John Samuel and William King. His daughter Mary remained unmarried and kept house for her unmarried uncle John until his death in 1822 . At some point after the death of her uncle, Mary met and worked with Emélie Tavernier Gamelin, who was beginning her work to alleviate the distress of the poor and sick in Montreal. This work eventually led to the foundation of the Soeurs de la Providence in 1844 with Madame Gamelin as the first Mother Superior. By the time Mary died in 1845 she had converted to Roman Catholicism. Unfortunately the extant papers contain little information about Mary, a gap which seems to have had little to do with her conversion. Her father, though a staunch 
Protestant, provided for her in his will and her half-brother John Samuel saw to it that its provisions were honoured.

Although John Samuel McCord (Figure 3) is without a doubt the most talented and cultivated of all the McCords, he was so unknown before the organization of his papers that he merited no biography in the Dictionary of Canadian Biography. Frederick Lock's portrait of J. S. McCord suggests a jolly cherubic, benevolent man quite different from the ravaged face and bleary expression of his better known but difficult younger brother $\mathbf{W}$ illiam King McCord who stares at us from the pages of Pierre-Georges Roy's Les Juges de la province de Québec. Born in Ireland during their parents' lengthy stay, John Samuel, 1801-1865 and William King, 1803-1858 arrived in Quebec in 1806. John Samuel's school reports suggest that he was a good student. In 1816 Daniel Wilkie awarded him first prize for "...Emminence in the Latin and Greek languages \& Conic sections in Elocution and the study of Rhetoric and writing and good Behaviour." $\mathrm{He}$ entered the law offices of Jean-Roch Rolland and Samuel Gale and was called to the bar in 1823 . In 1842 he became a Judge for St. John's and in 1844 he became a Judge of the Circuit Court for the District of Montreal. In 1857 he was appointed to the Superior Court for the District of Montreal.

In addition to the notes and correspondence on general legal matters, John Samuel's legal papers contain files on 110 legal cases as well as 51 bench books, McCord's notebooks of trials, for the years 1845 to 1865 , all meticulously kept and indexed.

John Samuel McCord had many interests beside the law. An accomplished amateur scientist, he was devoted to the study of both meteorology and botany. During his trips to the Eastern Townships as a Circuit Court Judge, he collected plants which he carried back to Montreal to be transplanted in the carefully planned gardens which surrounded his summer home, Temple Grove, near the site of the present day Montreal General Hospital. He almost certainly designed the house himself, in the form of a Greek temple, in accordance with his classical training. He felt that had they been able, the Greeks too, whould have constructed a temple in such a beautiful setting. At the back of his indexed legal notebooks on authorities and decisions, legal definitions and newspaper reports of trials, can frequently be found notes on the thermometer, the barometer, sun, moon and tide calculations and other entries of meteorological interest. During the 1830s and early 1840s John Samuel carefully observed and recorded meteorological information particularly on the island of Montreal. In his efforts to gather meteorological data on Montreal, he received permission from Sir John Colborne, Commander-in-Chief of the British forces in Canada, to have observations taken on St. Helen's Island where British regulars were garrisoned, during the course of the 1837-1838 uprisings. As a Freemason and a prominent member of the Natural History Society of Montreal, he shared the beliefs of many of his contemporaries in the ability of science to promote economic progress in his country and to overcome some of its social ills. John Samuel McCord's meticulous gathering of meteorological data testify to his faith in science. Doubtlessly, his son's passion for collecting and for meticulous documentation, was nurtured by these ideals.

McCord's archives contain letters from some of the leading scientists of his day, including Sir Charles Lyell, the renowned geologist who reproduced John Samuel's sketch of Montreal Mountain and his observations in his Travels in North America: with Geological Observations on the United States, Canada, and Nova Scotia, 2 volumes, London, 1845. He corresponded with Sir John Herschell of the Royal Society; and in September of 1837 Professor Charles Daubeny of Oxford visited him at Temple Grove where they compared actinometers. McCord found his instrument to "correspond within a fractional difference which would not amount to anything worth recording in the mean of several observations..." Besides his own charts McCord collected earlier charts dating back to 1799, including two journals kept by David Thompson, one of Canada's foremost geographers. In 1838 McCord's "Observations on the Solar and Terrestrial Radiation Made at Montreal" was published in The London, 
"When There Is No Vision, the People Perish."

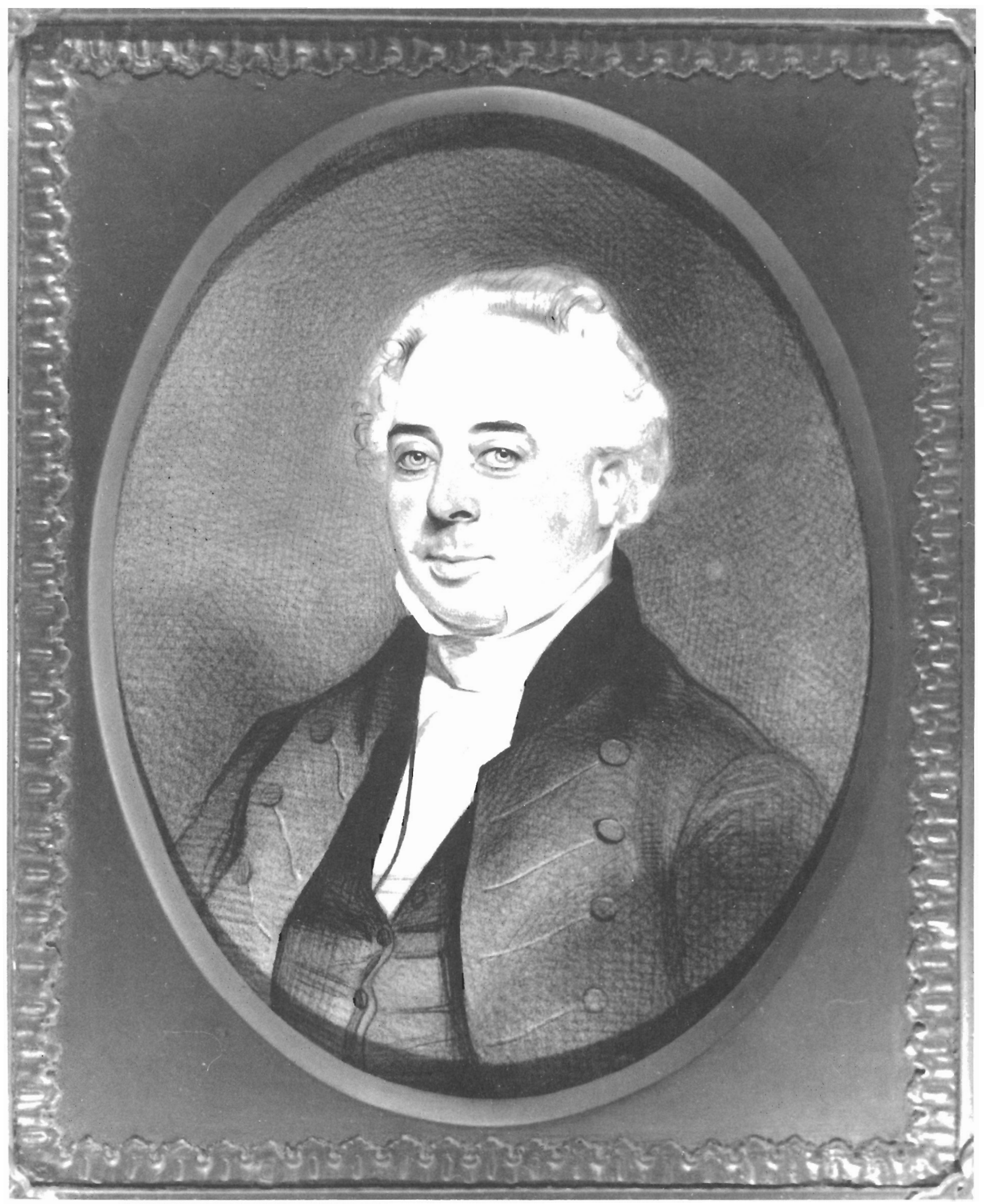

Figure 3. Portrait of John Samuel McCord by Frederick Lock, 1851. (McCord Museum of Canadian History, Montreal.) 
Edinburgh and Dublin Philosophical Magazine and Journal of Science. He was the corresponding secretary for the Natural History Society of Montreal. Distinguished surgeon and former Mayor of Montreal, William H. Hingston, inscribed on the fly leaf of his influential work, The Climate of Canada and its Relation to Life and Health, Montreal, 1884, "To D. R. McCord Esq, To whose father the writer is indebted for having his attention directed to) the subject of this volume. 8 August, 1885." Unfortunately in 1843 John Samuel recorded in one of his notebooks on climate and meteorology, "Having been appointed Distr. Judge for St. John's on the 10 June 1842 my personal metl. observations were suspended from that date, a subject I much regret particularly as the winter of $1842-3$ has proved a most extraordinary one, and many Phenomena have of course escaped my observation."12 In 1844 McCord sold his scientific instruments to McGill University. J. J. C. Abbott (future Prime Minister of Canada) deputy registrar and bursar acknowledged their receipt.

Perhaps one of the reasons why John Samuel McCord could approach Sir John Colborne about taking meteorological observations on St-Helen's Island even during the 1837-38 uprisings, a seemingly inopportune time, was that McCord was a prominent member of the militia. By March 1838 he was Lieutenant-Colonel of the Royal Montreal Cavalry and Commanding the lst Volunteer Brigade. His military papers contain information on the daily administration of the militia. The papers include correspondence with his superior officers, and with the officers under his command in the Montreal Volunteer Rifles, the Montreal Volunteer Artillery, the Montreal Light Infantry and the Royal Montreal Cavalry. His militia papers also contain returns, accounts, petitions, memos, general orders, and lists of equipment.

Among the John Samuel and William King McCord papers are 48 centimetres of material dealing with the administration of the Nazareth Fief which they inherited in 1829. John Samuel inherited more than the fief; he also had inherited the responsibility for an irresponsible brother co-owner, whose debrs due to drinking and gambling plagued John
Samuel until William King's death in $1856 .{ }^{13}$ Evidence of William King's financial problems begin in 1825. Debtors including William King's wife appealed to John Samuel for relief. William's career took him to England, the United States and Dublin where he became so destitute, he was obliged to pawn his watch. John Samuel repeatedly admonished William King to mend his ways and attempted to find him suitable employment. Finally, Wiliam King obtained the positions of police magistrate and justice of the peace, and by 1844 was appointed Judge of the Circuit Court of the district of Quebec. But this was not enough to keep him out of debt. So onerous was the burden that John Samuel considered purchasing William King's part of the Nazareth Fief, worth in total about $£ 27,500$ in capital with an income of $£ 1,650$. In 1852 on the back of a letter from Benjamin Holmes cashier of the Bank of Montreal, John Samuel endorsed a note to William King for $\mathfrak{\$} 500$. Eventually J. J. Day purchasd Wiliam King's property for $£ 8,000$. John Samuel was also responsible for the management of his wife Anne Ross' considerable estate.

John Samuel McCord played an active role in his community. He was a member of Christ Church Cathedral, a member of Synod, and their legal adviser. He served as ViceChancellor and Chancellor of Bishop's University, Lennoxville and helped found what later became Bishop's College School. He was a director of the Montreal General Hospital and served as chairman of the Trustees of the Protestant Burying Grounds. Ten files cover McCord's activities as a Freemason in which he served as Deputy Provincial Grand Master of the Provincial Grand Lodge for the District of Montreal and William Henry. There are five letters from William McGillivray, formerly the principle director of the North West Company, on Masonic matters, written just before McGillivray's death in London. The Museum possesses a Masonic jewel inscribed by McGillivray to McCord. Although little detailed work has been done on J. S. McCord, his diverse interests and the wealth of information in his papers make him a sympathetic subject for study. 
Among the McCord Papers are found a small but revealing section of Davidson Papers, preserved by John Samuel's wife, Anne Ross (Figure 4), his first cousin twice removed. Born in 1807, Anne was the second of eleven children born to David Ross, Q.C. 1770-1837, and Jane Davidson, 1789-1866. Jane Davidson's father Arthur Davidson had emigrated from Scotland to Quebec City in 1766. With an M.A. from King's College, Aberdeen, Arthur was admitted to the bar in 1771. In 1780 he settled in Montreal where he built up a considerable legal practice and held several minor government positions. In 1800 he was appointed to the Court of King's Bench for the District of Montreal. According to historian G. P. Browne, Davidson was "A welltrained, able and conscientious lawyer, unlike so many legal practitioners during the early years of British rule, he was clearly intent on improving both the standards of his profession and the quality, or at least the consistency, of the law." The collection contains accounts as well as one hundred and thirtyfour letters between Arthur Davidson, his family, friends, colleagues and merchants both in Canada and Britain. His comments on everything from his family's health to the shabby state of his wig, to the conduct of his colleagues presents us with a view of the daily struggles and concerns of a man building a professional career in a new land during a time when Europe was almost perpetually at war. Little escaped him. In a letter written in 1788 to his brother Walter, who is studying divinty and is considering a career in either the Church of England or the Church of Scotland, Arthur suggests, "there are essential errors which are suffered to prevail in both, it is in my opinion, of but little consequence whether a Clergyman follows them in the one or the other church. ${ }^{15}$ A year later he writes that Scotland is "a country where misery, oppression and injustice prevail, and which therefore every one that can (until the constitution and times mend much from what they are) should, in my opinion leave." ${ }^{16}$ To another brother about to arrive in Quebec, he advises, "...there is no such thing as doing business in Canada without understanding French." Nineteen letters to John Chalmers, in London, who acts as his tailor, banker, book and news- paper forwarder, give us an idea of the perils of long distance outfitting in 1778. "The yankeys having been so friendly as to ease me of a good part of the clothes you made for me last winter on their way to this place..." From 1795 to 1805 Davidson and David Ross corresponded regularly on legal matters whenever they were absent from Montreal.

There is a small collection of Ross financial papers, estate papers and correspondence. Advocate General David Ross K.C., 1770-1837, the son of John Ross, studied law and articled with Arthur Davidson in Montreal. Appointed King's Council in 1811, by 1813 he had begun to built an imposing neo-classical home for his family on the Champs de Mars. This house was, unfortunately, destroyed in the $1950 \mathrm{~s}$ in order to make room for a parking lot, since replaced by the Palais de Justice. Like many of his contemporaries he served in the militia during the War of 1812 .

In 1803 David Ross married Jane Davidson, daughter of Arthur Davidson and Jane Fraser. They had eleven children, nine of whom reached adulthood and received a sound education. Their eldest son Arthur attended Trinity College Cambridge and Lincoln's Inn and for a short period thereafter lived in Paris and Rome. Upon his return to Lower Canada 1827, he became a barrister. Anne, their next child attended school in Montreal and received private tutoring in drawing, painting, French, dancing and riding.

Unfortunately there are relatively few Anne Ross McCord papers except for twelve files covering an assortment of subjects from commonplace books to correspondence, sketches and watercolours. We know from her son David Ross McCord, however, that she exerted a strong influence on his life encouraging especially his love for history. She, like her son, was an avid collector, as is clear in the following letter, dated November 1824 from her brother Arthur at Trinity College.

I have secured for your museum some most rare gems of antiquity! It was but this morning that I purchased them at the sale of the late Dr. Clarke's curiosities; very cheap 
"When There Is No Vision, the People Perish."

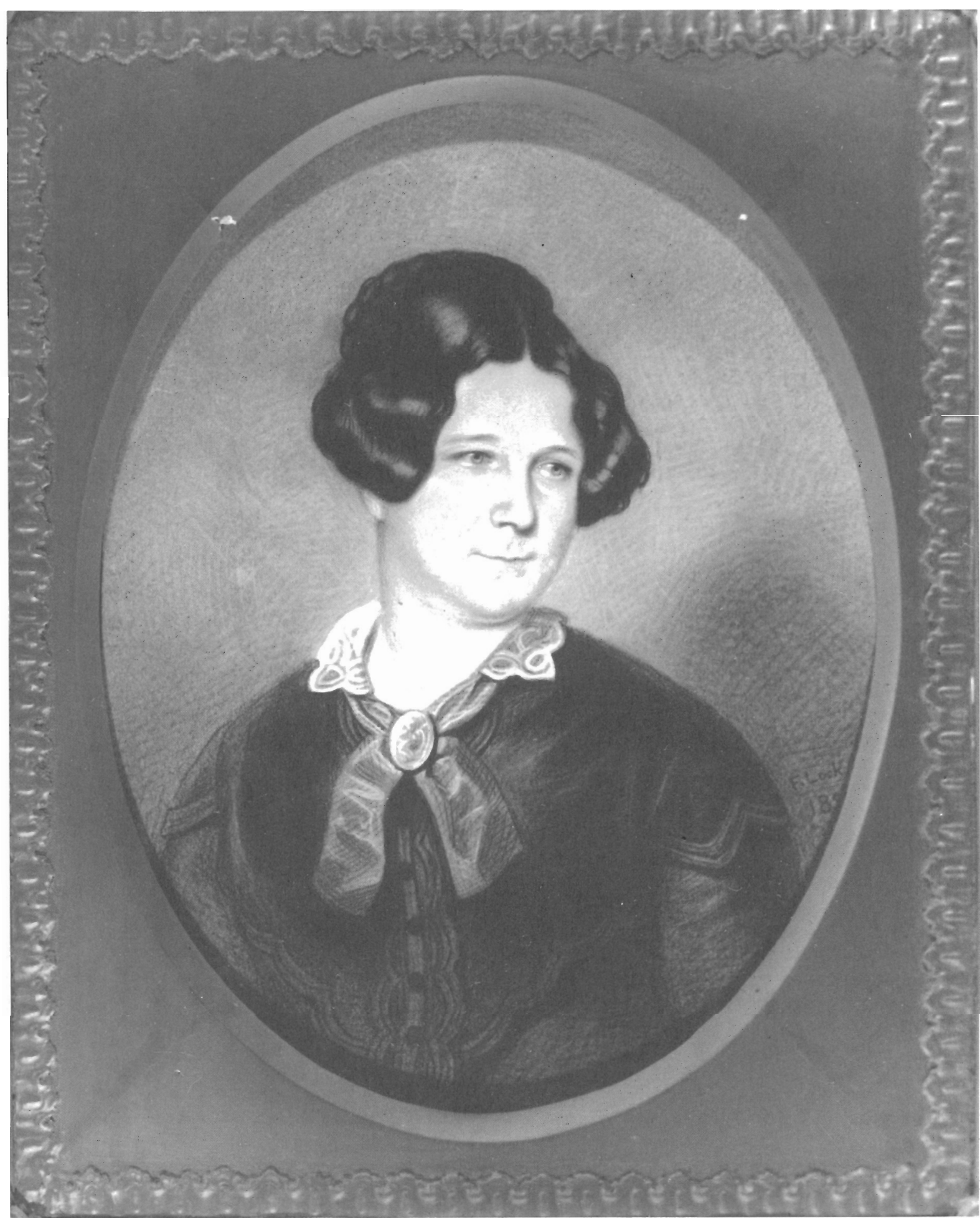

Figure 4. Portrait of Anne Ross McCord by Frederick Lock, 1851. (McCord Museum of Canadian History, Montreal.) 
as it was a very rainy day, $\&$ few of the dons ventured out. I was ruminating on the pleasure I should have in describing them to you in my next epistle...I proceed to inform you that I have a tablet on which is depicted in bas-relief, the figure of an Egyptian idol, from a Greek inscription on the forehead of which, Dr. Clarke proves it to be the god Hermes or Mercury, the very idol which the Israelites worshipped under the title of Baal. Also a piece of Rock Crystal from the tombs of the Incas in Peru. Both these Dr. C. has spoken of at large in his works, $\&$ of the former indeed there is an engraving; I shall write out extracts from the work, \& send them with the curiosities. Item a tripod, Lamp, lacrymatories, piece of Mosaic pavement, etc. etc. all which Dr. C. collected himself in Greece; \& a number of Cornish \& Devonshire minerals; the properties $\&$ scientific account of each of which Auldjo has promised to write out for you. I have not expended as yet $£ 4$. Do you not wish for the arrival of the box! I can fancy your eyes sparking!'?

It is easy to discover a further source of her son's passion for collecting. Two letters from her husband, John Samuel McCord whom she married in 1832, suggest a warm, charitable, competent lady. Her all too brief diaries kept for only sixteen months during the years 1821 , 1822 give us the best idea of her character and a world viewed through the eyes of a remarkably informed and perceptive thirteen and fourteen year old girl.

Mr. Van der Sluys is pretty well recovered but he has lost his situation which was $£ 500$ a year. He attacked Mr. Halkett in the street on the $17^{\text {th }}$ October, as Mr. H. was going to dinner at Mr. Auldjo's/ where Papa was to meet him/ and attempted to horsewhip him. Mr. H. had been treated in the same manner in the morning by $\mathrm{Mr}$.
McDonald, and was now armed with a pistol, which after warning Mr. V. he fired, and the contents entered his body. He is now fortunately almost recovered. $\mathrm{Mr}$. Halkett is a Lawyer, and being the cousin and brother in law, of Lord Selkirk, was employed by him. He recieved $[$ sic $]$ instruction from Lord S. to write a pamphlet in which the $\mathrm{N}$. West were greatly abused particularly Mr. S. MacGillivray, Mr. Van der sluys, and Mr. MacDonald. As he did not know these gentlemen even by sight, he merely abused them in obedience to the orders he recieved from Lord S. When the two companies united, all this was forgotten, but $\mathrm{Mr}$. McDonald was not allowed to become a partner, and this he resented, as also did Mr. Van der Sluys-this so annoyed the North West that they have taken his situation from him, which was that of Chief Book Keeper. At the time it happened it caused a great deal of disturbance, and revived all the old contentions, which had begun to rest in peace. Mr. Halkett was obliged to remain here till $\mathrm{Mr}$. Van der sluys began to recover, but he is now at Washington where he spends the winter. Mr. W. McGillivray and family, it is thought, will never return to this country-but Mr. S. MacGillivray returns in the spring. Mr. W. McG. had many enemies, but he will be much missed by his friends - he has left his carriage and horses with Mrs. Reid. Here, I believe, finishes this epitome. ${ }^{20}$

Her sense of humour is evident from her comments on the celebration of the construction of the Lachine Canal. "The Dinner at La Chine yesterday went off very well, but there were unfortunately a few broken heads among the Irish workmen, luckly, Irish heads can bear breaking two or three times in one day. The Commissioners entertained the workmen very handsomely, \& altogether at their own expense." If there are more diaries, they have 
unfortunately vanished. In those which survive it is clear that her powers of observation were keen and her wit sharp, and she would have had much to tell us as the wife of a prominent judge.

After her marriage she led a very active life as she was responsible for bringing up six children and for running two residences, one in the heart of the city and their summer home, "Temple Grove." Had she maintained her diaries they would have provided a privileged view of Montreal during a crucial period of its history. Her artistic energy was directed towards her water colour paintings of flowers, which Sir William Dawson declared were not only works of art but accurate enough to be used in teaching his class on botany. She participated in charitable works as a member of Christ Church Cathedral as well as secretary to the Montreal Protestant Orphan Asylum. At her death an account of her work described her contribution to the orphanage, "her wonderful tenacity of memory in regard to the orphans, her gentle manner, combined with the orderly and businesslike way with which she kept our records." 22

Of her six children, David Ross McCord proved to be the most dynamic. Her elder daughter Eleanor died in childbirth in 1863 at the age of 27 seventeen months after her marriage to George Lewis. Jane and Anne did not marry and lived quietly at Temple Grove with their brother David Ross McCord until his marriage. Two other sons had undistinguished careers in medicine and the army, John dying at the age of 27 and Robert at 36.

A few Montrealers still recall David Ross McCord climbing onto the bus outside his home (Figure 5) on Côte des Neiges and riding downtown to his Museum. Unfortunately by 1922 W. D. Lighthall, his friend, lawyer, and collector, was obliged to seek power of attorney over his client in order to protect the estate. The onset of arterial scelorsis made him a threat to his family and estate and he was sent to Homewood Sanitorium in Guelph where he remained, except for a few stormy visits to his wife at Temple Grove, until his death in 1930. Most people remembered McCord as an incredible eccentric, obsessed by his museum, a man who went to any length to obtain artifacts for his collection. Relatives hesitated to leave him alone in their drawing rooms, for fear of losing their prized possessions. Recently the Museum received a gift of three bound volumes of the "Canadian Courant and Montreal Advertiser" for the years 1807-1816. In making this gift the donor, Briton O. Smith of Boston recalled walking as a child with his father and being hailed by McCord from across the street. "When are you going to give me your newspaper?" McCord demanded. Mr. Smith had no intention of parting with his volumes but his son at the end of his life recalled the odd old man and wrote to the McGill Graduates' Society relating the story and asking if there existed a museum at McGill. The papers are now safely stored in the Archives of the McCord Museum. David Ross McCord had the last word, as he so often did.

David Ross McCord's passion for collecting came not only from his mother. Born into a home with a strong sense of the history, his father had commissioned the artist James Duncan to paint scenes of Montreal. In David Ross McCord's own day he commisioned the artist, Henry Bunnet, to record scenes of vanishing Quebec landmarks. John Samuel had firm ideas about his province and worked to insure that David Ross McCord was brought up to appreciate his country. He insisted that his son be fluent in both languages. The parent's teaching fell on fertile ground. McCord was a good student. After graduating from Montreal High School, he attended McGill University where he obtained his Bachelor of Arts in 1863 at the age of 19 , having won prizes in his third year in Essay and Moral Philosophy. Four years later he received his Master of Arts and his Bachelor of Civil Law in the same year. He became an advocate in 1868. Although he worked conscientiously at his practice and was named Queen's Counsel in 1895 it is hard to believe that his practice occupied the most creative periods of his life. There are only 27 files about his law practice although this certainly cannot represent his entire work.

Further study is needed in order to establish D. R. McCord's exact financial position. He inherited money from his father, largely based 


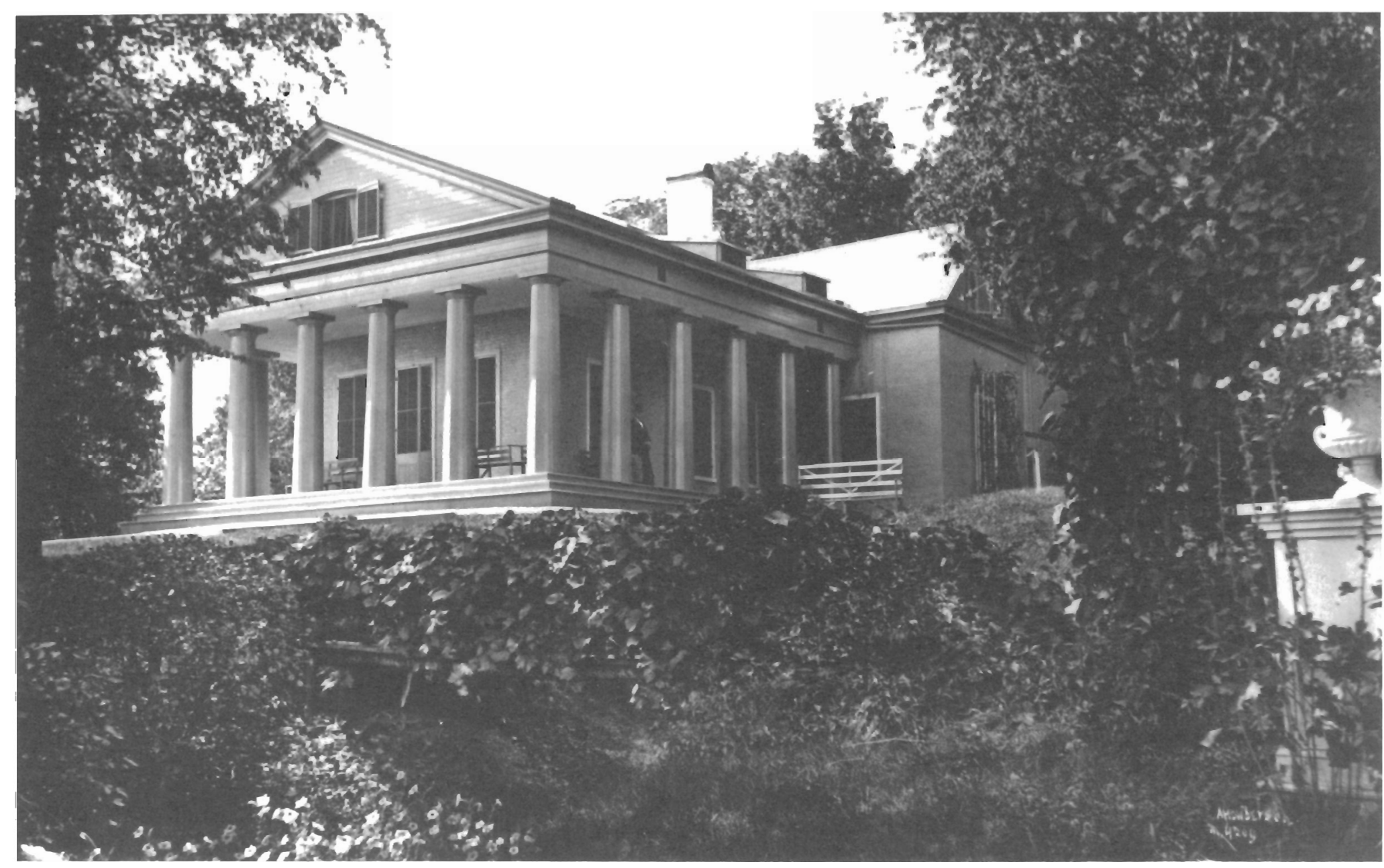

Figure 5. D.R. McCord's house, Temple Grove, Montreal, 1872. (Modern print from the original collodion glass plate negative taken by Alexander Henderson. McCord Museum of Canadian History, Montreal.) 


\section{"When There Is No Vision, the People Perish."}

on the proceeds of rents from the Nazareth fief. When the lease expired in 1890, McCord invested to some extent in real estate. Although he obtained many valuable objects as gifts, nevertheless he spent significant amounts purchasing what he could not obtain without charge, so much so that his sister Anne refused to leave money to the Museum in her will. In her opinion, enough had been sacrificed. In $1930 \mathrm{~W}$. D. Lighthall valued the contents of the Museum at $\$ 449,000$.

Over one third of the McCord Family Papers were produced by David Ross McCord. Five hundred and fifty-two files contain correspondence about his collection. As early as the $1860 \mathrm{~s}$ he began writing to collectors, antiquarians and dealers, as well as to the descendants of notables, and by the 1880 s he was completely engrossed in his attempts to build a collection of artifacts, documents and books illustrating the history of Canada. McCord shared many of the ideals of the imperialist movement and of its predecessor, Canada First. He believed in their faith in history as a means of defining Canadian character, their romantic view of native people, of New France and of the military and the loyalist contribution to the definition and defence of Canadian culture. It is no coincidence to find in his library a well-annotated copy of G. T. Denison's book Soldiering in Canada, published in 1900. Conscious of the importance of his work, McCord wanted his own papers kept so that they "should come back \& form part of the record-dossiers of the transactions-so that both correspondents' methods of analysis will be preserved for the future-questions \& answers-We are not living for ourselves, thank God, in this work." 23

One of the Museum's great assets is its possession of these letters, which provide systematic documentation of the collection of artifacts which McCord maintained from the start. As much as possible documents of historical interest accompanied artifacts. Any family which donated a portrait, sword, medal, uniform or anything else was solicited for its archives as well. Although McCord failed to persuade Lady Laurier to donate records, he convinced Hortense Cartier, the daughter of Sir George Etienne Cartier, to donate to his Museum what remained of his depleted records, which consisted of one metre of heterogeneous material. In McCord's mind no momento of the past was too trivial to retain. Above all he worked to retrieve the material record of his country's past.

The native people of Canada occupied a special place in his collection and the Council of the Six Nations granted him the Mohawk name Ronoshonni, "The Builder." Forty-eight files of his "collecting correspondence" refer to every imaginable feature of native culture, including extensive and detailed correspondence on papooses, wampum, scalps, silver, medals, quillwork, arrowheads, prayerbooks, axes, head dresses, tomahawks, ceremonial objects, paddles, vessels and portraits. Although extremely cautious of his money, McCord kept receipts for about $\$ 2,500$ paid to Mrs. M. Roberts of Halifax, from 1912 to 1919 for Mic Mac objects. McCord sketched a few of the objects onto the receipts. In the best nineteenth century collecting tradition, missionaries and public officials were canvassed as well as Sam Steele in his capacity as Superintendent of the North West Mounted Police. In 1920, McGill graduates were pressed into service. During the Paris Peace Conference in 1919, Prime Minister Sir Robert Borden received a letter from McCord suggesting that if Canada received reparations, they take the form of North West Coast Indian artifacts which had been avidly collected by German collectors during the nineteenth century. McCord hoped that his Museum would be the beneficiary of such an arrangement. McCord's records are not confined to his correspondence. He kept detailed accession records and collected books and articles which he annotated extensively in pencil, expanding the author's information or argument, giving further references, or refuting their arguments and listing his sources.

The arrangement of rooms in the McCord Museum when the Museum opened in 1922 reflected McCord's perception of Canadian History. Adopting the biblical quotation, "When there is no vision the people perish," McCord filled twelve rooms and two halls with artifacts grouped into the following subjects: Indians (Abenaki, Mic Mac, Iroquois, 
Plains and West Coast) in Room A; French Régime and Seven Years War, in Room B. The remaining ten rooms were devoted to Wolfe, McCords and related families (having no mean opinion of his family's achievements), Protestant Spiritual Pioneers, Roman Catholic Spiritual Pioneers, the American Revolution, China (porcelain), Quebec Province, Artists, Generals and Poets, Montreal and McGill University and finally the Arctic.

Four files of McCord's correspondence document his struggle to convince McGill University and several other institutions to accept the gift of his Museum. W. D. Lighthall was McCord's chief support and was anxious that McGill accept the collection and endowment. C. H. Gould, the University Librarian, Percy Nobbs, of the School of Architecture, and Sir Frederick Williams-Taylor, General Manager of the Bank of Montreal also put pressure on McGill to accept the collection. Lighthall watched over the progress of the Museum. Even after its opening Lighthall guided its administration especially when he perceived that the University was not living up to its agreement.

Accompanying the collecting correspondence are many other small but significant sections dealing with the rest of David Ross McCord's life, among them his application for the Beit Professorship of Colonial History at Oxford in 1905. Included are complicated estate papers, for McCord administered the Ross estate as well as his own. The collection covers his financial activities, his community activities, as well as the correspondence begun by his father in 1845 with the McCords of South Carolina which provides information on the American Civil War period. A somewhat incredible correspondence of 112 letters between McCord and his future wife, Letitia Caroline Chambers whom he married in Toronto in August of 1878 , provide insight into the man's character and pretensions. Letitia Caroline Chambers and David Ross McCord met during the course of his tenure as Chairman of the Board of Health. Letitia, a nurse, emigrated to Montreal from Ireland in the $1870 \mathrm{~s}$ where she managed the Civic Small-pox Hospital. After leaving the Hospital in January of 1878 , she moved briefly to Toronto where she taught a religious course at the Central Prison and was tutored in general deportment and music by a Mrs. Gordon. Self-improvement seems to have been the object of this sojourn. On the eighth of June, 1878, McCord wrote in a gentle vein:

Do you think I would be pleased with you if you were not ladylike. I am of course naturally anxious because circumstances placed you with people below you and you have acquired the use of expressions which are not elegant, and any one of them would injure you and I therefore requested you to begin at once to keep a close watch on every word and act, which I know you will do, as it is my wish-The habit of learning is soon acquired when one is in earnest to accomplish anything $\&$ to please... ${ }^{24}$

David Ross McCord's sisters Jane and Anne did not approve of the marriage and were probably unhappy about leaving Temple Grove. As well as rehabilitating his fiancée's manners, McCord spent a lot of time rehabilitating her place in the family tree. Discovering that she was descended from the Maunsell family, he quickly entered into correspondece with the more prominent living members and made sure that there was a substantial section on himself and his Museum in the three volume family history of the Maunsells.

On April 12, 1930 Davis Ross McCord died at the age of eighty-seven. Since his wife and sisters had predeceased him, his tangled estate was left to the Royal Institution for the Advancement of Learning for the purpose of maintaining the McCord National Museum.

McCord's collecting benefitted from Canadians' interest in their historic past which characterized the period from 1880 to 1920. On the $15^{\text {th }}$ of January, 1913, McCord was notified of an article in the "Times" about the discovery of a copy of Gray's "Elegy" annotated by General James Wolfe, a book which accompanied him to Quebec. On his way to the Plains of Abraham Wolfe is reputed to have 
stated that he would rather have written "The paths of Glory lead but to the grave," than to take Quebec. McCord acted immediately. But twelve days later he received a telegramme from England that the book was "Not at Present for sale." 25 In October of 1988 the Friends of the Thomas Fisher Rare Book Library with financial help from the Federal Cultural Properties Review Board presented this work to the University of Toronto Library, to mark the acquisition of its seven millionth book. McCord would have been delighted to have the book return to Canada. He would have been even happier had the book come to his Museum where he had laid a firm foundation for the establishment of a Museum of Canadian History with strong collections and a rich source of documentation.

\section{Notes}

1. In preparing this paper I would like to acknowledge the work of Elaine Holowach Amiot, Richard Vaudry and Tom Wien who worked on the inventory and prepared biographies of each of the more prominent members of the family. I would also like to acknowledge the help of Moira McCaffrey, Donald Fyson, Donald Wright and François Remillard.

2. National Archives of Canada (NAC), microfilm reel C2999-S series, vol. 19, p. 6701. Report of committee of the Governor's Council on refund of duties paid on importation of rum, Quebec, 24 May 1770.

3. Archives nationales du Québec, Montreal, 06, M-CN 601-29/10. Deed of Assignment John McCord Sr. to John McCord Jr. \& Thomas McCord, 11 Oct. 1793.

4. NAC, RG 4 B28 v.120 Shop licenses.

5. NAC, MG 11, C.O.42, vol. $28 \mathrm{ff}$ 147-151v. Carleton to Shelburne, Quebec, 20 Jan. 1768.

6. McCord Family Papers, file 5245, D. R. McCord to Lady Laurier, Montreal 1919.

7. For a fuller biography of Thomas McCord please see Elinor Kyte Senior's article in the Dictionary of Canadian Biography, vol. VI (Toronto, 1987), 432.

8. McCord Family Papers, file 207, Thomas McCord to Jacques Terroux, Montreal, 11 Aug., 1795.

9. Ibid., Dublin, 1 July, 1798, M 4409.

10. McCord Family Papers file 400.

11. McCord Family Papers, file 828, Notebook on climate and meteorology of North America, 1820s \& 1830s, (written c. 1836-43) 16 Sept., 1837 M18353.

12. Ibid., 4 Feb. 1843.

13. For a fuller biography of William King McCord, please see Jean-Claude Robert's article in the Dictionary of Canadian Biography, vol. VIII (Toronto, 1985), 524.

14. Dictionary of Canadian Biography, vol. V (Toronto, 1983), 226. 
"When There Is No Vision, the People Perish."

15. McCord Family Papers, file 1437 , Arthur Davidson to Walter Davidson, Montreal, 20 Oct. 1788.

16. Ibid., Montreal, 6 Aug. 1789.

17. Ibid, file 1438, Arthur Davidson to John Davidson, London, 25 March, 1780 M1553.17.

18. Ibid., file 1442, Arthur Davidson to John Chalmers, Oct. 1778, (draft, n.d.)

19. Private collection, Arthur Ross to Anne Ross, Trinity College, 17 Nov. 1824.

20. McCord Family Papers, file 1002, Anne Ross Diary, 2 Nov. 1821.

21. Ibid., 18 July 1821 .

22. Ibid., file 1000, Newspaper clippings.

23. McCord Family Papers 1766-1945, vol. II, (Montreal, 1986), Introduction.

24. McCord Family Papers, file 1852, D. R. McCord to L. C. Chambers, 8 June, 1878.

25. Ibid., file 5487 , on behalf of Vicar of Westerham to D. R. McCord, Westerham, 27 Jan. 1913. 